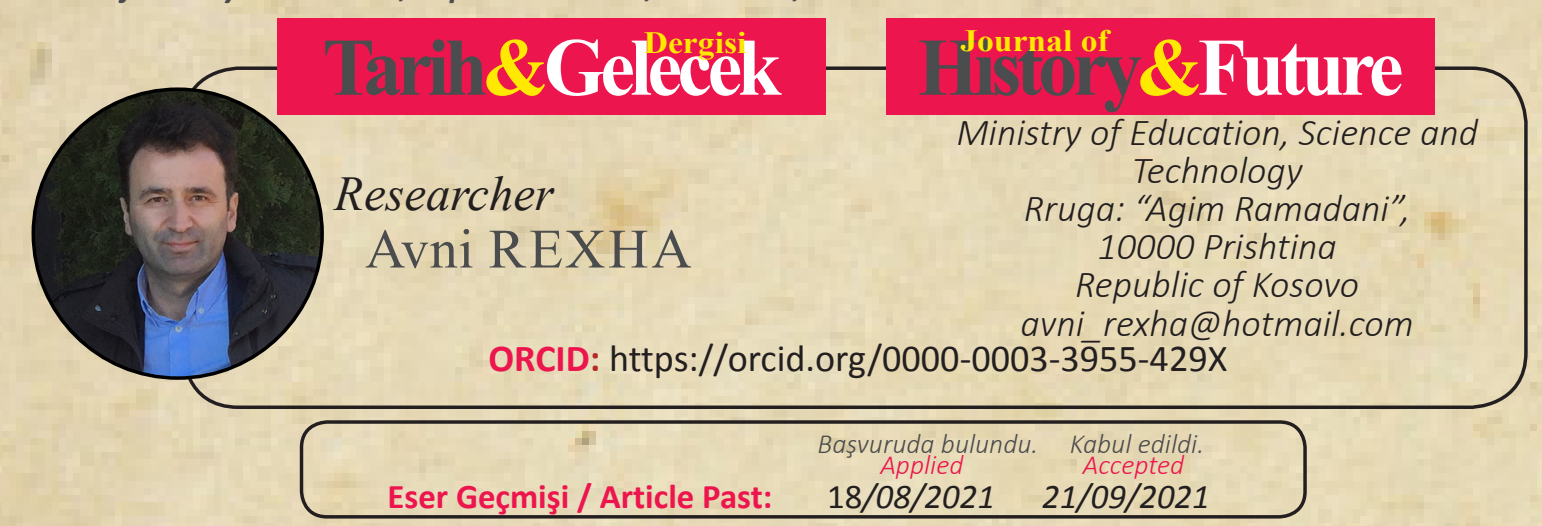

Araştırma Makalesi

DOI: http://dx.doi.org/10.21551/jhf.984408

Research Paper

Indexed by

ERIHPOUNALS

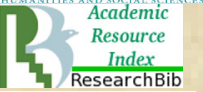

Q $\mathbf{I} \mid \mathbf{S A M}$

Oriinal Makale / Orginal Paper

\title{
The Ideopolitical Differentiation and Violence of The Serbian Rule Against Albanian Lecturers and Students at the University of Prishtina (1981-1990)
}

\author{
Sırbistan Hükümeti'nin Priștine Üniversitesi'nde Arnavut \\ Öğretmen ve Ö̆grencilerine Karşı İdeopolitik Farklılık ve Şiddeti \\ (1981-1990)
}

\section{Abstract}

The years 1966-1974 marked a turning point in the modern history of Kosovo. The political changes in Yugoslavia, which followed the fall of the Serbian hegemonic block, facilitated the efforts of the Albanian population to achieve national and political rights. The opportunity to continue education in the Albanian language was accompanied by the advancement of the constitutional position of the Socialist Autonomous Province of Kosovo within the Yugoslav federation. The opening of the University of Prishtina, the Academy of Sciences, scientific research institutes, cultural institutions, etc., resulted in the raising of the Albanian national consciousness not only in Kosovo but also in other areas inhabited by Albanians in the former Yugoslavia. In 1981, Albanian student demonstrations broke out in Kosovo, the main demand of which was to equalize Kosovo's legal status with other Yugoslav republics. But Yugoslav political circles viewed the demonstrations as an attempt to overthrow Yugoslavia's constitutional order. They were forcibly suppressed. At the same time, Serbian political circles, which had always tried to obstruct Albanian national achievements, took the opportunity to politically attack the University of Prishtina, which they considered a source of Albanian nationalism, and possibly to close it. Many lecturers and students were convicted, imprisoned, and expulsed from the University. Therefore, the paper "The ideopolitical differentiation and violence of the Serbian rule against Albanian lecturers and students at the University of Prishtina 1981-1990" aims to elaborate the approach of Yugoslav communist policy to the 1981 student demonstrations in Kosovo, the Yugoslav state violence against lecturers and students, and the measures that were taken to collapse the University of Prishtina, respectively ideological and political differentiation.

Key words: University, demonstrations, students, Communist League, differentiation, etc. 


\section{Öz}

1966-1974 yılları, Kosova’nın modern tarihinde bir dönüm noktasıdır. Yugoslavya'da Sırp hegemonik bloğunun çöküşüyle kendini gösteren siyasi değişimler, Arnavut nüfusunun ulusal ve siyasi haklara ulaşma çabalarını kolaylaştırdı. Yugoslav federasyonu içindeki Kosova Sosyalist Özerk Bölgesi'nin anayasal konumunun gelişmesiyle birlikte Arnavutça eğitime devam etme olanağ1 da sağlandı. Priştine Üniversitesìnin, Bilimler Akademisi’nin, bilimsel araştırma enstitülerinin, kültür kurumlarının vb. açılması, yalnızca Kosova'da değil, aynı zamanda eski Yugoslavya'da Arnavutların yaşadığı diğer bölgelerde de Arnavut ulusal bilincinin yükselmesiyle sonuçland1. 1981'de Kosova' da Arnavut ögrenci gösterileri patlak verdi. Bu gösterilerde öğrenciler Kosova'nın diğer Yugoslav cumhuriyetleriyle hukuki statüsü eşitlenmesi talebinş istediler. Ancak Yugoslav siyasi çevreleri, gösterileri Yugoslavya'ın anayasal düzenini yıkma girişimi olarak gördü. Göxterilere güç kulanarak, bastırıldılar. Bu durumda, her zaman Arnavut ulusal başarılarını engellemeye çalışan Sırp siyasi çevreleri, Arnavut milliyetçiliği için bir eğitim yuvası olarak gördükleri Priştine Üniversitesiıne siyasi olarak saldırma ve muhtemelen onu kapatma firsatını yakaladılar. Birçok profesör ve ögrenci mahkum edildi, hapsedildi ve üniversiteden atıldı. Bu nedenle, "Sırp hükümetinin 1981-1990 Priştine Üniversitesi>ndeki Arnavut profesörlere ve ögrencilere karşı ideolojik farklılaşması ve şiddeti” makalesi, Yugoslav komünist politikasının Kosova'daki 1981 ögrenci gösterilerine, Yugoslav devletinin profesörlere yönelik şiddetine yaklaşımını detaylandırmayı ve ögrenciler, Priştine Üniversitesìnin yıkılmasına yönelik alınan önlemleri, ideolojik ve siyasi farklılaşmayı yı amacı vardır.

Anahtar Kelimeler: Üniversite, gösteriler, öğrenciler, Komünist Birliği, farklılaşma vb.

\section{Introduction}

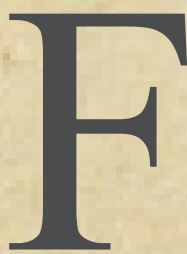

ollowing the student demonstrations of March 11, 1981, the Yugoslav political circles, from the lowest to the highest instances, gathered and discussed the events in Kosovo. The demonstrations were described as directed against the Yugoslav state, while the demonstrators were described as nationalists and irredentists. Everyone rushed to propose the most draconian measures, to present the most oppressive plans to those who took part in the demonstrations. ${ }^{1}$

The same attitude was also supported by the joint meeting of the highest provincial political leadership of Kosovo, which was held immediately after the demonstrations. After a long discussion, where student demands and slogans were reviewed, the demonstrations were by a majority of voters considered to be "in the service of hostile nationalist forces and tendencies". 2

The attitude that the majority of Kosovar leadership adopted meant a determination to stand behind the anti-Albanian policy of the Yugoslav communist nomenclature. This was the origin of

1 Basha Keçmezi Sabile, "Diferencimet Ideopolitike Ndaj Intelektualëve Shqiptarë Në Kosovë 19451990," January 5, 2010, http://www.zemrashqiptare.net/news/id_12255/Sabile-Ke\%C3\%A7meziBasha:-Diferencimet-ideopolitike-ndaj-intelektual\%C3\%ABve-shqiptar\%C3\%AB-n\%C3\%ABKosov\%C3\%AB-1945-1990.html.

2 Lita Qerim, Çështja Shqiptare Në RSFJ 1981-1990 (Përmbledhje Dokumentesh), (Shkup: Shoqata e historianëve shqiptarë në Republikën e Maqedonisë, 2014), 55-56. 
ideological and political differentiation, which as a process of cleansing the Albanian cadres was continuously developed in various forms until 1989, with the abolition of Kosovo's autonomy. ${ }^{3}$

The ideopolitical differentiation took place in all areas of life and work and included workers, pupils, students, lecturers, and in particular, the prominent educational, cultural, scientific and political cadres. Undoubtedly, the attack of Serbian rule was directed towards the University of Prishtina, whom they considered as a stronghold of Albanian nationalism and irredentism in Kosovo. Their aim was the complete collapse of the University and the removal of the university staff from the political and educational life in general. Therefore, this was the main reason why ideopolitical differentiation first began at the University of Prishtina.

At the beginning of the process, the Albanian intellect faced a dilemma: to line up with the demonstrators and bear the consequences of the persecution and arrest, or to condemn the demonstrations as Yugoslav leadership wished. In most cases, they were forced to tacitly approve the condemnation of the demonstrations or they tried to find a middle ground between surviving and maintaining the educational system in the hope that this situation would be overcome. Most of the lecturers were afraid of repression and admitted a kind of self-criticism that they had not been careful enough about the phenomena of nationalism, but in most meetings in organizational and party units of the Communist League, they did self-criticism in generalized forms without acknowledging that the demonstrations were counter-revolutionary and aimed at the overthrow of Yugoslavia. In most cases, the blame laid through police repressive actions. ${ }^{4}$

Aiming to "deepen the ideopolitical war and differentiation at the University of Prishtina", the University Action Conference on November 9, 1981, defined, elaborated and approved the detailed criteria for the evaluation of work, attitudes, conduct and responsibility regarding the inconsistent implementation of the Action Plan of the Provincial Committee of the Communist League of Kosovo. Each basic organization of the Communist League at the University of Prishtina had to evaluate separately its members, employees and students, based on the following criteria:

- "If any lecturer, associate and another employee, through his/her work in the period before the hostile demonstrations, through teaching or other forms, has deliberately helped to create a nationalist and irredentist worldview and action, showing nationalist euphoria to students and others;

- Is there any case of incitement and participation in the organization of hostile demonstrations and other actions in the line of nationalism and irredentism, ${ }^{5}$

- Who didn't pay attention to the realization of the Communist League policy for national equality, brotherhood, unification of nations and nationalities and their coexistence, and has opposed that policy from nationalist, chauvinist and other positions?

- If any of lecturers, associates and other staff through their attitudes and activity has abused the projected activities with the University of Tirana, particularly if anyone showed a flattering attitude towards those who came from that university, or who was behaved unworthily during his

3 Dushi Minir, Universiteti i Kosovës (1981-1983), (Prishtinë: Universiteti i Prishtinës, 2004), 269.

4 Dushi Minir, 274-275.

5 Dushi Minir, 271. 
stay in the People's Republic of Albania. ${ }^{6}$

There were other criteria similar to the above to be taken to differentiate the staff at the University of Prishtina. This course took place in almost all faculties of the university. The proposals and measures imposed were the dismissal from the Communist League and then from the work. After the analysis by the municipal committee of Communist League of Prishtina, in coordination with the working group established by decision no. 512 dated September 16, 1982, had jointly proposed:

a). To dismiss lecturer Ali Hadri from the Communist League due to the lack of commitment against Albanian nationalism and irredentism;

b). The municipal committee of the Communist League to issue the following measures against the below-mentioned lecturers:

- Hamdi Gashi, professor assistant at the Agricultural Faculty - dismissal from the Communist League;

- Ali Aliu, professor at the Philosophy Faculty - last warning;

- Agim Vinca, professor at the Philosophy Faculty - last warning;

- Murat Blaku, professor at the Philosophy Faculty - last warning;

- Fehmi Agani, professor at the Philosophy Faculty - last warning;

- Hivzi Islami, professor at the Mathematic-Natural Sciences Faculty - last warning;

- Riza Binishi, professor at the Medical Faculty - last warning.

In the course of ideopolitical differentiation the communist bodies issues following measures against below-mentioned lecturers:

- Reshit Alidema, professor at the Mathematic-Natural Sciences Faculty - dismissal from the Communist League;

- Muje Rugova, professor at the Mathematic-Natural Sciences Faculty - dismissal from the Communist League;

- Nexhat Daci, professor at the Mathematic-Natural Sciences Faculty - last warning;

- Mustafa Baca, professor at the Mathematic-Natural Sciences Faculty - last warning;

- Idriz Barani, professor at the Mathematic-Natural Sciences Faculty - last warning;

- Rexhep Qosja, professor at the Philosophy Faculty - last warning; ${ }^{7}$

Furthermore, under the pretext of "incompetence and irresponsibility following staff was discharged from managerial positions:

- Hamdi Sylejmani was discharged from the position of Head of Communist League Action Conference of Technical Faculty;

- Ahmet Gashi was discharged from the position of Head of Communist League Action

6 Dushi Minir, 288-289.

7 Dushi Minir, 288-289. 
Conference of Agricultural Faculty;

- Fadil Batalli was discharged from the position of Head of Institute of Medical Faculty;

Due to their "unacceptable omissions and attitudes", the following lecturers were fired: Ymer Jaka, Fehmi Rexhepi, Ali Hadri, Pajazit Nushi and Fehmi Agani - the Philosophy Faculty, Rashit Alidema and Mark Krasniqi - the Mathematic-Natural Sciences Faculty, Gazmend Zajmi - the Law Faculty, Sahadete Mekuli, Jusuf Rexhepi, Skender Boshnjaku and Shefqet Canhasi - the Medical Faculty. ${ }^{8}$

The illegal dismissal of academic staff from the teaching at the university was done without any argument, but by slandering non-existent things and making various assumptions. Due to "open hostile activity and support of demonstrations and counter-revolutionary efforts", the following lecturers had been punished: Ukshin Hoti, Muhamet Ternava, Shaqir Shaqiri and Shemsi Recica - the Philosophy Faculty, Ruzhi Sefa - the Technical Faculty, and Halil Alidema - administrative staff - the Philosophy Faculty. All these individuals had previously been dismissed from the League of Communists and their basic organizations. ${ }^{9}$

From 1981 to $1988,1,004$ Albanian teachers and 1,873 Albanian primary and secondary school students were convicted on various political grounds in Kosovo, while 179 students were expulsed from the University of Prishtina. ${ }^{10}$

The ideopolitical differentiation was accompanied by other measures aiming to collapse the University of Prishtina. Following this course, in the year 1986 the Presidency of Yugoslavia and the Presidency of the Communist League of Yugoslavia, issued the following conclusions: early retirement of Albanian lecturers, formation of ethnically mixed classes and bilingual teaching, etc. But these measures had been rejected by the Kosovo Assembly. ${ }^{11}$

The differentiation and expulsion of teaching staff continued throughout 1989. During 198990 about 700 Albanian teachers were fired. The Serbian police had received many powers, which were out of its competencies. Without any warning, Serbian police brutally interfered in educational facilities. $^{12}$

The ideopolitical differentiation was implemented against students as well. Following the Student Demonstration of 1981, 19 students were dismissed from the Communist League, 365 students were removed from the records of the Communist League and 157 students were banned to follow the teaching. For similar reasons, 113 students were expulsed from the dormitory. Due to "misconduct and participation in demonstrations", 38 students were expulsed and banned to enrol in the next five years, 78 students were expulsed and banned to enrol in the next one year, 82 students received the last written warning before the expulsion, whereas 34 students were sentenced

8 Dushi Minir, 290.

9 Koliqi Hajrullah, Mbijetesa e Universitetit Të Prishtinës 1991-1994 (Prishtinë: Universiteti i Prishtinës, 1995), 18.

10 “Aktuelnosti u Vaspitanju i Obrazovanju,” no. br. 1/1989 (1989), 33.

11 Demi Zeqir, Zhvillimi i Sistemit Edukativo-Arsimor Në Kosovë Mbi Bazën e Legjislacionit Arsimor 1945 1990 (Prishtinë: Libri Shkollor, 2005), 323.2005

12 Koliqi Hajrullah, 40 Vjet Të Tempullit Tonë Të Diturisë (Prishtinë: Universiteti i Prishtinës, 2010), 20. 
to reprimand. ${ }^{13}$

Following this course, 568 Albanian students were denied the right to study or were expulsed. In the period 1981-82 and 1990-91, the number of Albanian students decreased by 11,068 or $35.93 \%$, respectively from 30,804 to 19,736 . This was a result of ideopolitical measures and increasingly difficult economic circumstances. ${ }^{14}$

From the academic year 1982-83 until 1989 there were restraining orders for admission of new students in the University of Prishtina. These restraining orders contained the names, surnames, addresses or exact data of Albanian students who would not be allowed to follow studies. These lists were kept in the state security organs or had disappeared altogether, as it was the attempt case to destroy the student admission list for the years 1981-82 to 1989-90. The lists of potential candidates banned to enrol in higher education institutions were compiled by two bodies: municipal assemblies and the General defence organization. Each municipality was tasked to draft a list of students from Kosovo and from other areas inhabited by Albanians in former Yugoslavia (Macedonia and Montenegro). The lists were submitted to the University of Prishtina. The list included not only the names of new students but of current students as well. There were not listed the reasons, but only basic features of a student or his/her family regarding the "hostile activities". Being unable to classify the subjects that had submitted such lists, we are giving their number for each academic year processed and published by Mr. Abdyl Rama:

- academic year 1981-82 - 156 students (8 of them from Struga and Ohrid) were banned;

- academic year 1982-83 - 178 students were banned;

- academic year 1983-84 - 243 students were banned;

- academic year 1984-85 - 269 students were banned;

- academic year 1985-86 - 265 students were banned;

- academic year 1986-87 - 179 students were banned;

- academic year 1987-88 - 236 students were banned;

- academic year 1988-89 - 84 students were banned;

- academic year 1989-90 - 184 students were banned; ${ }^{15}$

\section{Conclusion}

The ideopolitical differentiation had serious consequences for the University of Prishtina in general and for lecturers and students in particular. Under the pretext of ideopolitical differentiation, the most prominent Albanian scientific cadres and the most distinguished students were imprisoned, convicted and fired. The focus of Serbian violence was particularly directed against faculties that promoted the raising of national consciousness, such as the Faculty of Philosophy. The Serbian violence aimed to destroy and eventually close the University of Prishtina, which was a source

13 Dushi Minir, 290-291.

14 Universiteti i Prishtinës 1970-2005 (Prishtinë: Universiteti i Prishtinës, 2005), 23.

15 “Gazeta Zëri,” June 15, 1991. 
of national education not only for Albanians from Kosovo but also from other areas in the former Yugoslavia.

\section{Bibliography}

“Aktuelnosti u Vaspitanju i Obrazovanju,” no. br. 1/1989 (1989).

Basha Keçmezi Sabile. "Diferencimet Ideopolitike Ndaj Intelektualëve Shqiptarë Në Kosovë 1945-1990,” January 5, 2010. http://www.zemrashqiptare.net/news/id_12255/ Sabile-Ke\%C3\%A7mezi-Basha:-Diferencimet-ideopolitike-ndaj-intelektual\%C3\%ABveshqiptar\%C3\%AB-n\%C3\%AB-Kosov\%C3\%AB-1945-1990.html.

Demi Zeqir. Zhvillimi i Sistemit Edukativo-Arsimor Në Kosovë Mbi Bazën e Legjislacionit Arsimor 1945-1990. Prishtinë: Libri Shkollor, 2005.

Dushi Minir. Universiteti i Kosovës (1981-1983),. Prishtinë: Universiteti i Prishtinës, 2004.

“Gazeta Zëri.” June 15, 1991.

Koliqi Hajrullah. 40 Vjet Të Tempullit Tonë Të Diturisë. Prishtinë: Universiteti i Prishtinës, 2010. 1995.

. Mbijetesa e Universitetit Të Prishtinës 1991-1994. Prishtinë: Universiteti i Prishtinës,

Lita Qerim. Çështja Shqiptare Në RSFJ 1990-1981 (Përmbledhje Dokumentesh),. Shkup: Shoqata e historianëve shqiptarë në Republikën e Maqedonisë, 2014.

Universiteti i Prishtinës 1970-2005. Prishtinë: Universiteti i Prishtinës, 2005. 